\title{
Self-reported needle-stick injuries among dentists in north Jordan
}

Y. Khader, ${ }^{1}$ S. Burgan ${ }^{2}$ and Z. Amarin ${ }^{3}$

$$
\begin{aligned}
& \text { الإبلاغ الذاتي عن إصابات وخز الإبرة بين أطباء الأسنان في شمال الأردن }
\end{aligned}
$$

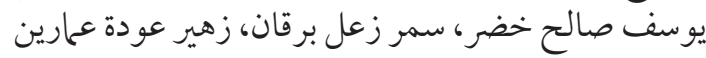

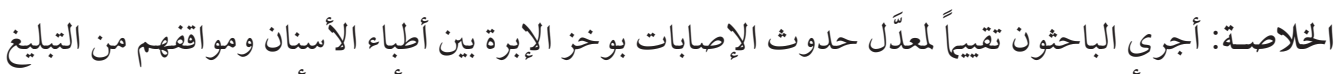

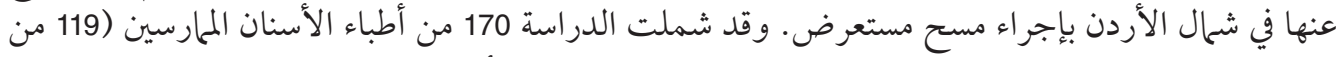

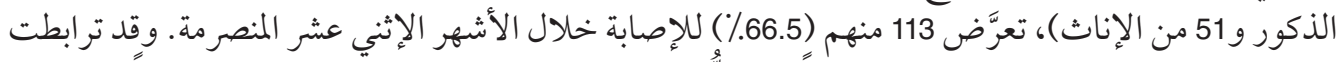

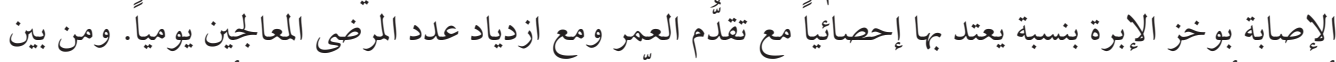

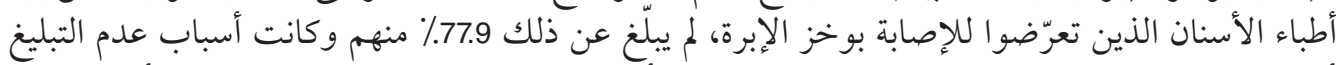

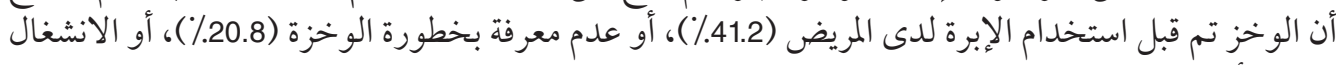

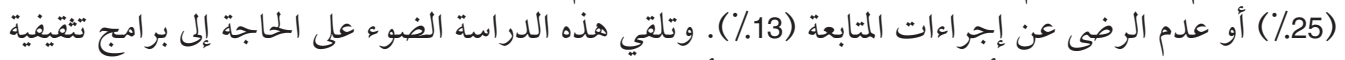

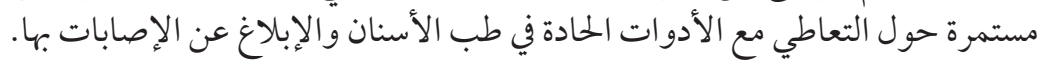

ABSTRACT The incidence of needle-stick injuries and the reporting attitudes among dentists in the north of Jordan were assessed with a cross-sectional survey. The study included 170 general dental practitioners (119 males and 51 females), of whom 113 (66.5\%) were injured within the preceding 12 months. Needle-stick injury was significantly associated with higher age and a higher number of patients treated daily. Of those who were injured, $77.9 \%$ did not report the injury. Reasons for not reporting needle-stick injury were: because it took place before use on a patient $(41.2 \%)$, ignorance of the risk $(20.8 \%)$, being busy $(25.0 \%)$ and dissatisfaction with follow-up procedures (13.0\%). The study highlights the need for continuous education programmes about handling of sharp dental instruments and reporting injuries.

Blessures par piqûre d'aiguille chez les dentistes du nord de la Jordanie declarées par les intéressés eux-mêmes

RÉSUMÉ Une étude transversale a été réalisée afin d'évaluer l'incidence des blessures par piqûre d'aiguille et les attitudes vis-à-vis de la déclaration de ces blessures chez les dentistes du nord de la Jordanie. Elle a porté sur 170 dentistes généralistes (119 hommes et 51 femmes), dont 113 (66,5\%) s'étaient blessés au cours des 12 mois précédents. Ces blessures étaient significativement associées à un âge élevé et à un grand nombre de patients traités chaque jour. Parmi les dentistes qui s'étaient blessés, $77,9 \%$ n'avaient pas déclaré leur blessure, et ce pour les raisons suivantes : parce qu'ils s'étaient blessés avant d'utiliser l'aiguille sur un patient (41,2\%), par ignorance du risque (20,8 \%), parce qu'ils étaient trop occupés $(25,0 \%)$ ou parce qu'ils n'étaient pas satisfaits des procédures de suivi $(13,0 \%)$. L'étude met en évidence la nécessité de programmes de formation continue sur la manipulation des instruments dentaires piquants et la déclaration des blessures.

${ }^{1}$ Department of Public Health and Community Medicine, Jordan University of Science and Technology, Irbid, Jordan. ${ }^{2}$ Department of Oral and Maxillofacial Surgery, Oral Medicine, Oral Pathology and Periodontology, Faculty of Dentistry, University of Jordan.

${ }^{3}$ Department of Obstetrics and Gynaecology, Jordan University of Science and Technology, Irbid, Jordan (Correspondence to Z. Amarin: zoamarin@hotmail.com).

Received: 16/01/06; accepted: 06/08/06

المجلة الصحية لشرق المتوسط، منظمة الصحة العالمية، المجلد الخامس عشر، العدد (، 9 +. 


\section{Introduction}

Serious infections can be transmitted in the dental practice when percutaneous injuries occur. Hepatitis B virus (HBV), hepatitis $\mathrm{C}$ virus (HCV), and human immunodeficiency virus (HIV) infections have been recognized as occupational hazards for dentists and other health care professionals $[1,2]$. The extent to which practising dentists follow recommendations to minimize their risk of a needle-stick injury varies. Neither the magnitude of the risk of needlestick injury nor the practices associated with it have been defined [3-6]. However, the transmission risk is influenced by the type and number of microorganisms present in the blood, presence of visible blood on the needle, depth of the injury and size and type of needle used [7].

Dentists' reports of compliance with recommended infection control practices and universal precautions against $\mathrm{HBV}$ and HIV infection increased between 1994 and 1995, but most dentists apparently have not adopted universal precautions [8]. Adherence to infection control procedures, especially barrier protection, has been linked to keeping the incidence of these infections low [9]. Recommended infection control practices that apply to all settings in which dental treatment is provided are available [10].

Although needle-stick injury among dental health care workers has been explored in several industrialized nations, very few data are available from developing countries. No data have been reported on needle-stick injuries among dentists in Jordan. Therefore, this study was conducted to assess the incidence of needle-stick injuries among dentists in the north of Jordan and describe their attitudes towards reporting such injuries.

\section{Methods}

The study was conducted between 1 November and 31 December 2004. The sampling frame was 414 practising dentists who were listed in the updated register of the Jordan Dental Association. The sample size was calculated assuming a prevalence of needle-stick injury within the preceding 12 months of $60 \%$ of dentists. The calculated sample size with $\alpha$ precision of $\pm 7.5 \%$ and confidence level of $95 \%$ was 164 . Using a random numbers table, a sample of 180 dentists was selected to compensate for non-response.

A structured, self-administered questionnaire was designed to describe the occurrence of needle-stick injuries among dentists. The questionnaire sought information about sociodemographic characteristics such as age, sex, marital status, years of experience and average number of patients treated daily. The questionnaire included information about the frequency of being stuck by a needle or a sharp instrument while at work during the last year, and the circumstances of the most recent needle-stick injury (before use on patient, during use on patient, after use on patient, disposal-related or any other specified circumstances). The definition of a needle-stick injury was a percutaneous injury of any depth caused by a small-, medium- or large-bore hollow syringe needle which did or did not involve visible blood at the time of injury. A yes/ no response was used to assess whether the dentist reported the injury to a family medicine health worker or to an emergency medical service.

All dentists were visited in their work place and verbal consent to participate was obtained. The respondents were assured about confidentiality. Continuous variables were described using mean and standard 
deviation (SD). All categorical variables were described using frequency tables. Data analysis was performed using SPSS, version 11.5. The chi-squared test was used to assess the association between categorical independent variables and being injured.

\section{Results}

Of the 180 selected Jordanian general dental practitioners, $170(94.4 \%)$ agreed to participate in this study (119 males and 51 females). Their mean years of professional experience was 9.3 (SD 6.8) years, range 1 to 32 years, and their mean age was 34.0 (SD 7.7) years, range 23 to 55 years, with approximately $76.5 \%$ being younger than 40 years. A total of 143 (84.1\%) dentists had been vaccinated against HBV infection.
Overall, 113 (66.5\%) of the dentists had been injured by a needle-stick at least once during the preceding year. About one-third $(33.5 \%)$ of dentists had not been injured, $16.5 \%$ had been injured once, $22.6 \%$ twice, and $27.4 \%$ on more than 2 occasions.

The incidence of needle-stick injuries by demographic characteristics and workrelated variables is shown in Table 1. Needlestick injury was significantly associated with increased age $(P=0.048)$ and increased number of patients treated daily $(P=0.045)$.

The circumstances of the needle-stick injuries are given in Table 2. Among those injuries, $32.7 \%$ occurred before injection, $30.1 \%$ occurred during injection, and $30.9 \%$ occurred after injection. Only $6.2 \%$ of injuries were sustained during disposal.

Of the injured dentists, $77.9 \%$ had never reported any of their injuries. Reasons for not

\begin{tabular}{|c|c|c|c|c|c|}
\hline \multirow[t]{2}{*}{ Variable } & \multicolumn{2}{|c|}{ Not injured } & \multicolumn{2}{|c|}{ Injured } & \multirow[t]{2}{*}{$P$-value } \\
\hline & No. & $\%$ & No. & $\%$ & \\
\hline \multicolumn{6}{|c|}{ Age group (years) } \\
\hline$<30$ & 26 & 39.4 & 40 & 60.6 & 0.048 \\
\hline 30-39 & 24 & 37.5 & 40 & 62.5 & \\
\hline $40+$ & 7 & 17.5 & 33 & 82.5 & \\
\hline Total & 57 & 33.5 & 113 & 66.5 & \\
\hline \multicolumn{6}{|l|}{ Sex } \\
\hline Male & 38 & 31.9 & 81 & 68.1 & 0.501 \\
\hline Female & 19 & 37.3 & 32 & 62.7 & \\
\hline \multicolumn{6}{|c|}{ Marital status } \\
\hline Single & 24 & 34.3 & 46 & 65.7 & 0.861 \\
\hline Married & 33 & 33.0 & 67 & 67.0 & \\
\hline \multicolumn{6}{|c|}{ Years of experience } \\
\hline$<5$ & 15 & 25.4 & 44 & 74.6 & 0.254 \\
\hline $5-<10$ & 19 & 36.5 & 33 & 63.5 & \\
\hline $10+$ & 23 & 39.0 & 36 & 61.0 & \\
\hline \multicolumn{6}{|c|}{ No. of patients per day } \\
\hline$<10$ & 35 & 40.7 & 51 & 59.3 & 0.045 \\
\hline $10+$ & 22 & 26.2 & 62 & 73.8 & \\
\hline
\end{tabular}

المجلة الصحية لشرق المتوسط، منظمة الصحة العالمية، المجلد الخامس عشر، العدد (، 9.?؟ 
Table 2 Circumstances of needle-stick injuries among Jordanian dentists $(n=170)$

\begin{tabular}{lcr}
\hline Injury occurred: & No. & $\%$ \\
\hline Before injection & 37 & 32.7 \\
Opening ampoule & 10 & 8.8 \\
Opening needle cap & 13 & 11.5 \\
Recapping before use & 14 & 12.4 \\
During injection & 34 & 30.1 \\
After injection & 35 & 30.9 \\
During disposal & 7 & 6.2 \\
\hline
\end{tabular}

reporting the needle-stick injury were: because it had happened before being used on a patient $(41.2 \%)$, perception of little or no risk to themselves $(20.8 \%)$, being busy $(25.0 \%)$ and dissatisfaction with follow-up procedures after reporting the injury $(13.0 \%)$.

\section{Discussion}

This cross-sectional survey investigated needle-stick injuries only among dentists, in contrast to most other studies which evaluated needle-stick injuries among health care workers in general. The frequency of needle-stick injuries among dentists in this study $(66.5 \%)$ is less than that of health care workers in other studies. Chen et al. reported that between $71 \%$ and $76 \%$ of Taiwanese nursing personnel had experienced needle-stick and sharps injuries [11] and Guo et al. found that the prevalence of needle-stick injuries among Taiwanese health care workers ranged from $61 \%$ to $93 \%$ [12]. On the other hand, the frequency of needle-stick injuries in our study is higher than the $58 \%$ reported in the only regional study on such injuries in dental health care workers in Saudi Arabia [13].

Identifying the circumstances of injuries is important. Being stuck during needle recapping after use and during injection are the most common and most serious needle-stick injuries as this has the potential for $\mathrm{HBV}, \mathrm{HCV}$ and $\mathrm{HIV}$ infection. In our study, $12.4 \%$ of injuries were sustained during recapping and before being used, and $11.5 \%$ of injuries were sustained during the opening of the needle. This type of injury is less risky to dentists, but, if the needle is subsequently used, it is potentially risky to patients. We found that $6.2 \%$ of injuries were caused at the disposal stage. These are areas that may be amenable to improvement through participation in training related to infection prevention and provision of appropriate sharps disposal containers.

The non-reporting of needle-stick injuries in this study and the reasons for it are disturbing; $77.9 \%$ of dentists did not report the injury. These results are in agreement with those of Guo et al. who found that $81.8 \%$ of all injuries and exposures were not reported by Taiwanese health care workers [12]. Reasons for not reporting injuries indicate a need for continued education about the risk of acquiring blood-borne pathogens from such injuries $[14,15]$. HBV vaccination [16], which remains low in developing countries [17], the use of post-exposure prophylaxis [18] and the use of improved engineering controls may circumvent some of the shortfalls in this area.

One of the limitations of our study is that recall bias may have occurred in the responses, especially for events that may have taken place a long time prior to the study. More rigorously designed studies are required to further assess adherence to infection control guidelines [19].

In conclusion, the general incidence of needle-stick injuries and reporting attitudes among dentists found in this survey are of concern. Safer work practices and instrumentation and continued worker education, with particular regard to post-treatment handling of sharp dental instruments and equipment, may reduce occupational blood exposure among dentists in Jordan. 


\section{References}

1. Klein RS et al. Occupational risk for hepatitis $C$ virus infection among New York City dentists. Lancet, 1991, 338:1539-42.

2. Mast EE. Alter MJ. Prevention of hepatitis $B$ virus infection among health care workers. In: Ellis RW, ed. Hepatitis $B$ vaccines in clinical practice. New York, Marcel Dekker, 1993:295-307.

3. Drelich EV. Reducing the risk of needlesticks: methods used to reload syringes. Journal of the American Dental Association, 1997, 128:55-9.

4. Stewardson DA et al. Occupational exposures occurring among dental assistants in a UK dental school. Primary dental care, 2003, 10:23-6.

5. Naidoo S. Dentists and cross-infection. Journal of the Dental Association of South Africa, 1997, 52:165-7.

6. Haiduven DJ et al. A survey of percutaneous/mucocutaneous injury reporting in a public teaching hospital. Journal of hospital infection, 1999, 41:151-4.

7. Cleveland JL et al. Use of HIV postexposure prophylaxis by dental health care personnel: an overview and updated recommendations. Journal of the American Dental Association, 2002, 133:1619-26.

8. McCarthy GM, MacDonald JK. Improved compliance with recommended infection control practices in the dental office between 1994 and 1995. American journal of infection control, 1998, 26:24-8.

9. Schuman NJ, Owens BM, Turner JE. Survey of hepatitis $B$ exposure and sharps injuries in dental health-care professionals. Compendium of continuing education for dentists, 1996, 17:986, 990-5.

10. Centers for Disease Control. Guidelines for infection control in dental health care settings, 2003. Morbidity and mortality weekly report, 2003, 52(RR17):1-61.

11. Chen YY, Yang GY, Liu CY. [Injuries to nursing personnel by sharp objects of medical apparatus and their causes]. Veterans general hospital nursing, 1996, 3:322-31 [in Chinese].

12. Guo YL et al. Needlestick and sharp injuries among health care workers in Taiwan. Epidemiology and infection, 1999, 122:259-65.

13. Paul T. Self-reported needlestick injuries in dental health care workers at the Armed Forces Hospital Riyadh, Saudi Arabia. Military medicine, 2000, 165:208-10.

14. Zakrzewska JM, Greenwood I, Jackson J. Introducing safety syringes into a UK dental school-a controlled study. British dental journal, 2001, 190:88-92.

15. Cuny E, Fredekind R. OSHA blood borne pathogens rule-revisions and clarifications. Compendium of continuing education for dentists, 2002, 23:191-4.

16. Yengopal V, Naidoo S, Chikte UM. Infection control among dentists in private practice in Durban. South African dental journal, 2001, 56:580-4.

17. Duffy RE et al. Evaluating infection control practices among dentists in Valcea, Romania, in 1998. Infection control and hospital epidemiology, 2004, 25:570-5.

18. Cleveland JL et al. Use of HIV postexposure prophylaxis by dental health care personnel: an overview and updated recommendations. Journal of the American Dental Association, 2002, 133:1619-26.

19. Gordon BL et al. Systematic review of adherence to infection control guidelines in dentistry. Journal of dentistry, 2001, 29:509-16. 